\title{
Microsurgical clipping of a small anterior choroidal artery aneurysm: technical pearls
}

\author{
Gregory Glauser, Omar Choudhri
}

Neurosurgery, Hospital of the University of Pennsylvania, Philadelphia, USA

\section{Correspondence to} Gregory Glauser,

Gregory.glauser@uphs.upenn. edu

Accepted 29 March 2019
Check for updates

(C) BMJ Publishing Group Limited 2019. No commercial re-use. See rights and permissions. Published by BMJ.

To cite: Glauser G,

Choudhri O. BMJ Case

Rep 2019;12:e230085.

doi:10.1136/bcr-2019-

230085

\section{DESCRIPTION}

This case is a presentation of technical tenets for the microsurgical clipping of an anterior choroidal artery aneurysm. The patient described in this case was a 75 -year-old woman who presented with the worst headache of her life, involving the left side of her head. The patient was found to have a CT-negative, lumbar puncture-positive subarachnoid haemorrhage, from a $4-5 \mathrm{~mm}$ left anterior choroidal artery aneurysm on angiographic studies. Endovascular options were considered to be high risk for this patient due to the small size, wide neck of the aneurysm as well as multiple choroidal perforators. Stent coiling was not considered the best option given the concern for a subarachnoid haemorrhage. The patient described in this case made an uncomplicated postoperative recovery and was discharged to home, without

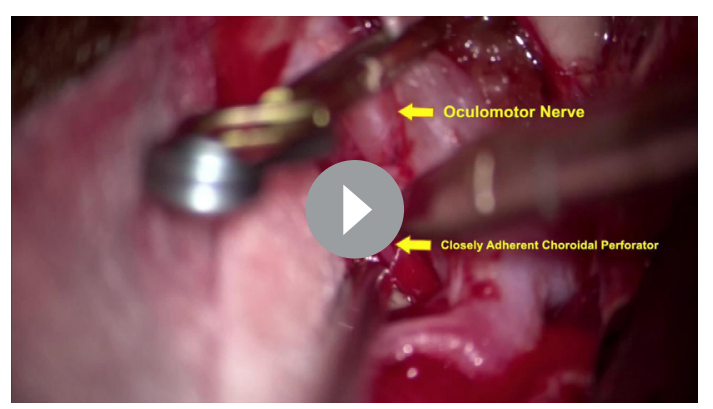

Video 1 Anterior choroidal artery aneurysm; aneurysm clipping; subarachnoid haemorrhage; cerebrovascular. developing vasospasm or any other subarachnoid-associated complications. This case is valuable to the literature as anterior choroidal aneurysms are small and treacherous. Thus, it is important to not overclip these aneurysms, a key technical note illustrated in video 1 . Considering that these arteries are quite unforgiving with multiple perforators and supply posterior limb of internal capsule, thalamus and optic tract, it is important to use all operative adjuncts during these cases, such as indocyanine green angiography, intraoperative cerebral angiography as well as neurophysiological monitoring particularly motorevoked potentials.

\section{Learning points}

- Operative adjuncts for intraoperative monitoring.

- Anterior choroidal artery aneurysm.

- Uncomplicated postoperative recovery.

Contributors $O C$ performed the procedure and provided video narration. GG performed critical video editing and preparation for publication.

Funding The authors have not declared a specific grant for this research from any funding agency in the public, commercial or not-for-profit sectors.

Competing interests None declared.

Patient consent for publication Obtained.

Provenance and peer review Not commissioned; externally peer reviewed.

Copyright 2019 BMJ Publishing Group. All rights reserved. For permission to reuse any of this content visit https://www.bmj.com/company/products-services/rights-and-licensing/permissions/

BMJ Case Report Fellows may re-use this article for personal use and teaching without any further permission.

Become a Fellow of BMJ Case Reports today and you can:

- Submit as many cases as you like

- Enjoy fast sympathetic peer review and rapid publication of accepted articles

- Access all the published articles

- Re-use any of the published material for personal use and teaching without further permission

For information on Institutional Fellowships contact consortiasales@bmjgroup.com

Visit casereports.bmj.com for more articles like this and to become a Fellow 